\title{
Determination of the growth performance and soil protection ability of the Caper (Capparis sp.) in eroded site in semi-arid region of Artvin, Turkey ${ }^{[*]}$
}

\author{
Turan YÜKSEK ${ }^{1 *}$ Filiz YÜKSEK ${ }^{2} \quad$ Mehmet ÖZALP $^{3} \quad$ Zafer ÖLMEZ $^{3}$ \\ ${ }^{1}$ Recep Tayyip Erdogan University, Department of Landscape Architecture, Rize, Turkey \\ ${ }^{2}$ Forestry and Water Affairs, Directorate of Eastern Black Sea Forestry Research Institute, Trabzon, Turkey \\ ${ }^{3}$ Artvin Coruh University, Department of Forestry Engineering, Artvin
}

\begin{abstract}
In this study, the growth performance and soil protection ability of the Caper (Capparis sp) in eroded site in semi-arid region of Artvin, Turkey were investigated. For this purpose, the experimental plot at the site included a randomized complete block with four replicates (a total of 8 experimental plots: 2 treatments $\times 4$ replicates). Each plot was 20-m long $\times 5-m$ wide, which is wide enough to minimize edge effects and large enough for downslope rills to develop. Between 2006 - 2008, water and sediment accumulated in sediment deposited tanks were measured. Then, with the help of these values, the runoff, the amount of transported sediment and the concentration of transported sediment were calculated. In addition, the development of the caper seedlings has been observed and recorded. As a result of the research, the average survival percent of caper sapling in 2006 was found to be $21 \%$. While, the mean height of caper seedlings varied between $4.6 \mathrm{~cm}$ and $6.1 \mathrm{~cm}$ in 2006, it has been varied between $5.2 \mathrm{~cm}$ and $8.18 \mathrm{~cm}$ in 2007. As a result of the statistical analysis, there were significant differences in terms of runoff, sediment yield and sediment concentration according to season and years, but no significant differences were observed between bare area and caper experimental sites. It has been determined that the adaptation of the caper in the eroded soil and its development is not at the desired level. It is thought that severe summer drought during the growing season negatively affects the survival and development of the caper saplings in the first years of planting. The survival rate of the caper and its low development could not prevent the erosive effect of the rain. It can be said that severe summer drought and soil characteristics (e.g: soil texture, soil water content, etc...) have significant effects on growing and survival rates of caper saplings.

It can be more useful to use combination with additional erosion control techniques (e.g., soil protection techniques) to make erosion control in this kind of sites where there is irregular and inadequate rainfall.
\end{abstract}

Keywords: Caper, eroded site, semi-arid, runoff, sediment, sediment concentration, Artvin.

${ }^{[*}$ This study was submitted in IFES (International Forestry and Environment Symposium) and published in Abstract book of proceedings.

\section{Artvin (Türkiye)'nin Yarı Kurak Erozyonlu Alanlarında Kapari’nin Toprak Koruma Yeteneği ve Büyüme Performansının Belirlenmesi}

Öz: Bu çalışmada Artvin'de yart-kurak sahalarda kaparinin gelişimi ve toprak koruma yeteneği araştırılmıştır. Bu amaçla her bir işlem için rastlantıl tam bloklar deneme desenine göre, her biri 4 yinelemeli $\left(4 \times 100 \mathrm{~m}^{2}\right) 4$ adet kalıcı blok oluşturulmuştur. Bu boklarda her bir işlem için yüzeysel akış ölçüm parselleri oluşturulmuştur. 2006-2008 yılları arasında meydana gelen yüzeysel akış sonucu tanklarda biriken su ve taşınan sediment miktarı ölçülmüş̧ür. Daha sonra bu değerler yardımıyla yüzeysel akış yüksekliği, taşınan sediment miktarı ve taşınan sediment konsantrasyonu hesaplanmıştır. Ayrıca parsellere dikilen kaparinin gelişimi izlenmiştir. Araştırma sonucunda kapari parsellerinde 2006 yllında ortalama yaşam yüzdesi \% 21 olarak bulunmuştur. 2006 yllında kapari parsellerindeki boy gelişimi 2.7-6.9 cm arasında iken; 2007 yılında ise bu değer 16.3-68.7 cm olmuştur. Yapılan istatistik analiz sonucunda yüzeysel akıs yüksekliği, taşınan sediment miktarl ve sediment konsantrasyonu bakımından mevsimlere göre ve yıllara göre istatistiksel anlamda önemli farklllıklar gözlenirken, çıplak parsellere göre kapari ile erozyon kontrolü yapılmış parselde anlamlı farklılıklar gözlenmemiştir. Kaparinin araştırma sahası erozyona uğramış topraklardaki adaptasyonunun ve gelişmesinin arzulanan seviyede olmadı̆̆ tespit edilmiştir. Büyüme mevsimi boyunca yaşanan yaz kurakliğı dikimin ilk yıllarında bitkinin hayatta kalmasın ve gelişimini olumsuz etkilediği düşünülmektedir. Kaparinin hayatta kalma oranının ve gelişiminin az olması yağmurun erosiv etkisinin engelleyecek kapalılığın oluşmamasıyla sonuçlanmıştır. Şiddetli yaz kuraklı̆̆ ve toprak özelliklerinin (toprak tekstürü, toprak su sabitleri, vb.) türün gelişimi ve türün yaşam yüzdesi üzerinde etkili olduğu söylenebilir. Erozyona uğramış ve vejetasyon döneminde düzensiz ve yetersiz yă̆ışların olduğu yerlerde; bu türün ilave erozyon kontrolü teknikleri (toprak koruma teknikleri) ile kombine edilerek kullanılması erozyon kontrolünün daha başarılı olmasını sağlayabilir.

Anahtar sözcükler: Kapari, erozyon, yüzeysel akış, sediment, sediment konsantrasyonu, Artvin

${ }^{[*}$ Bu çalışma IFES (Uluslararası Ormancıllk ve Çevre Sempozyumu) 'nda sunulmuş ve Bildiri Özeti kitabında yayınlanmıştır. 


\section{GíRíş}

Erosion is a very important environmental problem both in Turkey and worldwide (Yüksek and Yüksek, 2015). Soil erosion by water has been considered to be the major cause for loss of soil nutrients and reduced plant productivity (Zhou et al., 2008). Although many methods are used to prevent erosion; using of shrub and grass species in different ways to fight against the impact of water erosion is a widely used practice (Andreu et al., 1998). It is expressed in many studies that plant cover was an effective method of preventing soil and nutrient loss (Zhang et al., 2010). The vegetation cover reduces the effect of rain erosivity, especially on the ground, and keeps the soil in place by covering its roots with the soil, improving the physical and chemical properties of the soil (Angima et al., 2002; Kothyari et al., 2004; Babalola et al., 2007; Mohammad and Adam, 2010; Nunes et al., 2011; Yüksek and Yüksek, 2015). However, in semi-arid areas and in delicate ecosystems damaged, it is difficult to develop effective plant species in order to improve the existing vegetation cover and prevent erosion. In addition, this eroded areas has a negative effect on the plant development, because the rain is inadequate when plant is needed the most. In order to achieve the desired success in erosion control studies in semi-arid areas, choice of species suitable for the field in eroded sites is very important (Yüksek and Yüksek, 2007). Therefore, in such erosion areas, species that are high abiotic stress tolerance and grow fast to cover the land easily and thus reduce the erosive effect of rain are foreground. The caper plant belonging to the family of Capparacecaea is also stated to be able to be used easily in erosion control by covering and protecting the soil surface with deep root descent system, embrace, climber and spreader form (Kelkit ve Müftüoğlu, 2001). It is stated that the caper is naturally found in this region, it is characterized by xerophyte, it can easily reach to rainy spring and dry summers over $40^{\circ} \mathrm{C}$ and $350 \mathrm{~mm}$ of annual rainfall and can be used for soil protection in erosion control works (Ölmez, 2001). Although there are many studies on the use of some species to prevent plant growth and erosion in semi-arid areas (Andreu et al., 1998; Chirino et al., 2006; Li et al., 2006; Martinez Raya et al., 2006; Zhou et al., 2008; Xu et al., 2009; Zhang et al., 2010; Mohammad and Adam 2010; P. Garcia-Estringana et al., 2013; Yüksek and Yüksek, 2015). The development of this plant in soil in eroded sites in semi-arid lands and detailed data on erosion prevention ability are insufficient.

The aim of this study is to assess plant development of Capparis ovata Desf. and to determine runoff, sediment yield and sediment concentration at different time periods in semi-arid area.

\section{METHODOLOGY}

Research area is situated in the Yusufeli district of Artvin (40 46'35 " north, 41 49'03" east) northeast of Turkey, with an average elevation of 1050 meters a.s.l. According to observation values between 1974 and 2000, Yusufeli district has an average temperature of $14.2{ }^{\circ} \mathrm{C}$ and an annual total precipitation of $289.2 \mathrm{~mm}$. 1974-2000 record of Yusufeli meteorological station, $40 \mathrm{~km}$ far away from the study area, which is the nearest station to Pamukçular watershed, annual precipitation was $350 \mathrm{~mm}$. According to the data of the Yusufeli meteorological station $22.41 \%$ of the annual precipi-tation occurs in spring, $18.45 \%$ occurs in summer, $25.77 \%$ occurs in fall and $33.37 \%$ occurs in winter. According to the climate diagram of the study area by Thornthwaite, therewas strongly a water deficiency from May $15^{\text {th }}$ to November $15^{\text {th }}$ (See Fig. 1) (Yüksek and Yüksek, 2011). The annual average temperature was 15.40 ${ }^{\circ} \mathrm{C}$, average temperature in summer (June-July-August period) varied between 23 and $27{ }^{\circ} \mathrm{C}$, average highest temperature varied between 29 and $34{ }^{\circ} \mathrm{C}$ As can be seen from Figure 1, after April the water is approached and there is severe drought from May to June to the middle of October. The geological formation in the study area consists of two strati-graphic units: (i) a lower unit of pillowed and massive basalt and basaltic andesite intercalated with some thin-bedded silts and shales, and (ii) an upper unit of shallow-water sedimentary rocks with some interbedded basic volcanic rocks (Lower-Middle Jurassic shales and sandstones (Hamurkesen formation), Upper-Lower Cretaceous lime-stones (Berdiga formation), (Dokuz, 2000).

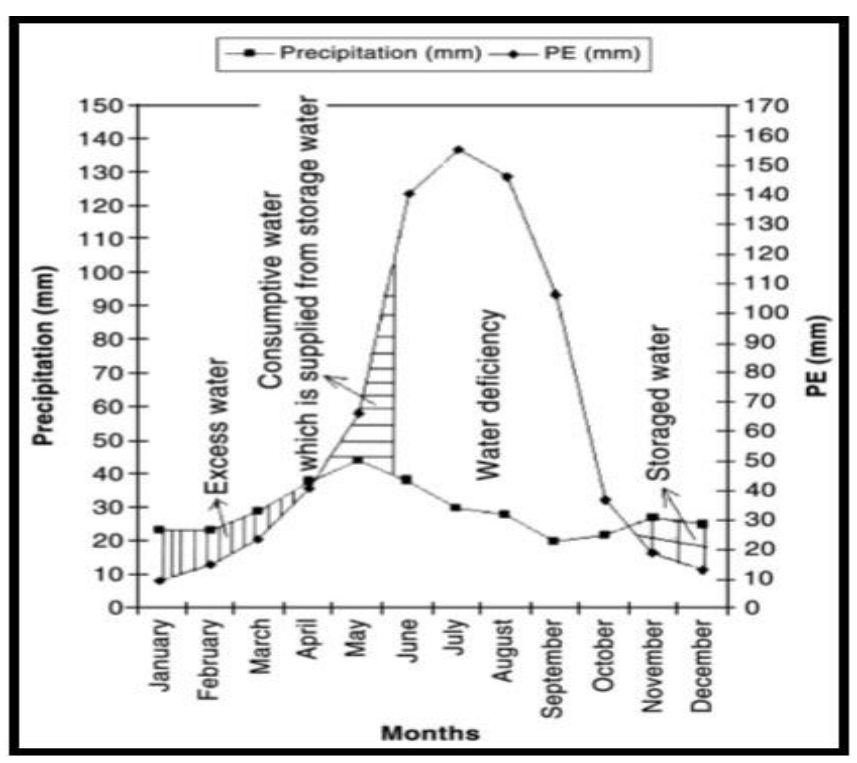

Figure 1. Climate diagram of Yusufeli area by Thornthwaite (period 1974-2000) (Yüksek and Yüksek, 2011).

The average land slope of the study area is $20 \%$. The soil characteristics of the study area were given in Table 1 (Yüksek et al., 2009). The natural vegetation covered in the area is sparse due to extreme destructiveness and drought, and even the soil remains bare. There are mostly bush and herbaceous taxa in the research area. The main 
woody and herbaceous taxa found in the alanda are Quercus petreae (Matt.) Liebl. Juniperus oxycedrus L., Paliurus spina-christi Mill, Eleagnus angustifolia L., Capparis ovata Desf., Crataegus monogyna Jacq., Rosa canina L., Lotus corniculatus L., Dactylis glomerata L., Astragalus ssp., Bromus ssp., Poa ssp., Carex ssp., Paspalum ssp. The experimental plots were established as "a randomized complete block design with four replications".

Table 1. Soil characteristics of experimental plots in research area (Yüksek et al., 2009).

\begin{tabular}{|c|c|c|c|}
\hline Soil Properties & Soil Depth (cm) & Bare Plot & Caper Plot \\
\hline \multirow{3}{*}{ Sand (\%) } & $0-10$ & 43.46 & 46.22 \\
\hline & $10-30$ & 49.88 & 50.79 \\
\hline & $30-50$ & 39.78 & 43.70 \\
\hline \multirow{3}{*}{ Clay (\%) } & $0-10$ & 32.10 & 29.11 \\
\hline & $10-30$ & 25.23 & 25.72 \\
\hline & $30-50$ & 37.86 & 33.50 \\
\hline \multirow{3}{*}{ Silt (\%) } & $0-10$ & 24.23 & 24.67 \\
\hline & $10-30$ & 24.90 & 23.49 \\
\hline & $30-50$ & 22.35 & 22.80 \\
\hline \multirow{3}{*}{$\begin{array}{l}\text { Bulk density } \\
\left(\mathrm{g} / \mathrm{cm}^{3}\right)\end{array}$} & $0-10$ & 0.96 & 0.90 \\
\hline & $10-30$ & 1.18 & 1.28 \\
\hline & $30-50$ & 1.23 & 1.26 \\
\hline \multirow{3}{*}{$\begin{array}{l}\text { Particle } \\
\left(\mathrm{g} / \mathrm{cm}^{3}\right)\end{array}$} & $0-10$ & 2.50 & 2.52 \\
\hline & $10-30$ & 2.67 & 2.61 \\
\hline & $30-50$ & 2.62 & 2.58 \\
\hline \multirow{3}{*}{ Total porosity (\%) } & $0-10$ & 61.52 & 64.17 \\
\hline & $10-30$ & 55.81 & 50.65 \\
\hline & $30-50$ & 52.86 & 51.12 \\
\hline \multirow{3}{*}{$\begin{array}{l}\text { Soil organic } \\
\text { matter }(\%)\end{array}$} & $0-10$ & 2.58 & 2.62 \\
\hline & $10-30$ & 2.41 & 1.85 \\
\hline & $30-50$ & 1.82 & 1.73 \\
\hline \multirow{3}{*}{$\mathrm{N}(\%)$} & $0-10$ & 0.11 & 0.14 \\
\hline & $10-30$ & 0.04 & 0.08 \\
\hline & $30-50$ & 0.02 & 0.04 \\
\hline \multirow{3}{*}{$\begin{array}{l}\text { Available } \\
\text { Phosphorus (ppm) }\end{array}$} & $0-10$ & 48.97 & 45.54 \\
\hline & $10-30$ & 21.18 & 37.14 \\
\hline & $30-50$ & 19.21 & 25.41 \\
\hline \multirow{3}{*}{$\mathrm{Ca}^{++}(\mathrm{me} / 100 \mathrm{~g})$} & $0-10$ & 21.28 & 21.19 \\
\hline & $10-30$ & 21.93 & 21.51 \\
\hline & $30-50$ & 21.43 & 21.45 \\
\hline \multirow{3}{*}{$\mathrm{Mg}^{++}(\mathrm{me} / 100 \mathrm{~g})$} & $0-10$ & 1.13 & 1.17 \\
\hline & $10-30$ & 1.18 & 1.19 \\
\hline & $30-50$ & 1.20 & 1.21 \\
\hline \multirow{3}{*}{$\mathrm{CaCO}_{3}(\%)$} & $0-10$ & 35.89 & 36.60 \\
\hline & $10-30$ & 35.83 & 36.10 \\
\hline & $30-50$ & 36.91 & 39.89 \\
\hline \multirow{3}{*}{$\mathrm{K}^{+}(\mathrm{me} / 100 \mathrm{~g})$} & $0-10$ & 0.33 & 0.32 \\
\hline & $10-30$ & 0.30 & 0.30 \\
\hline & $30-50$ & 0.28 & 0.28 \\
\hline \multirow{4}{*}{$\begin{array}{l}\text { Cation exchange } \\
\text { capacity } \\
(\mathrm{me} / 100 \mathrm{~g})\end{array}$} & $0-10$ & 25.65 & 25.90 \\
\hline & $10-30$ & 24.90 & 26.10 \\
\hline & $30-50$ & 25.10 & 26.05 \\
\hline & $0-10$ & 7.65 & 7.61 \\
\hline \multirow[t]{2}{*}{$\mathrm{pH}\left(1 / 2.5 \mathrm{H}_{2} \mathrm{O}\right)$} & $10-30$ & 7.69 & 7.65 \\
\hline & $30-50$ & 7.72 & 7.73 \\
\hline
\end{tabular}

For this purpose, runoff plots of $20 \mathrm{~m}$ length (in the direction of slope) and $5 \mathrm{~m}$ width, each with four repetitions in the same parent material, same aspect, same soil type, same elevation and same slope group were set up in the study area. The edges of the generated test plots were isolated so that they are not affected by the surrounding superficial flow and similar hydrological events.

In the plots where the capers planted, the land was destroyed as little as possible and mechanically cleaned the entire area. Then, on October 27, 2005, $2+0$ potted caper seedlings originating from Artvin were planted by a distance of $1.5 \mathrm{~m}$ x $2 \mathrm{~m}$ distance. Thus, a total of 30 caper seedlings were planted in each of the plots and a total of 120 caper seedlings were planted in experimental plots. Growing media of potted caper seedling consisted of a mixture of forest soil, stream sand and cow manure $(1: 1: 1)$.

The average shoot length measured in caper plots. The measurements were repeated monthly in the vegetation period basis during research. The plant cover was removed using herbicide in the bare plots and no soil treatment was done on the bare plots. A rainfall gauge was placed in the study area to determine the precipitation of the plots. Surface runoff and sediment sampling were carried out for 3 years after erosive rainfall. The results of the study were evaluated using the SPSS statistical package program.

The effects of different treatments on runoff, sediment yield and sediment concentration on caper and bar plots were analyzed by $\mathrm{T}$ test. Soil conservation ability of caper according to years and seasons was analyzed with ANOVA.

\section{RESULTS AND DISCUSSION}

The distribution of the amount of rainfall during the study period was presented in Table 2 . When the rainfall values are examined, it is determined that rainfall decreases linearly with years. Monthly variation of precipitation during the year is quite different from the years. According to average values, the highest rainfall occurred in April.

The periods when the temperature is high and the plant needs the most water are June, July and August in the research area. However, only $23.7 \%$ of annual total rainfall falls in this period. In addition, the level of evaporation in this period is at the top of the year. These negative factors are thought to negatively affect plant development in the field of research. In caper plots, the average life percentage of $21 \%$ in 2006 is thought to be caused by inadequate and irregular rainfall in summer and severe evapotranspiration.

It is emphasized that in order to complete the development of caper, regular irrigation should be done especially in the first years (Özturan 2007; Ölmez, 2001). The average plant height development of the caper during the observation years was given in Figure 2. 
Table 2. Monthly rainfall (mm) and mean annual rainfall for the study period 2006-2008.

\begin{tabular}{|c|c|c|c|c|c|c|c|c|c|c|c|c|c|}
\hline Year & 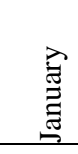 & 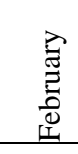 & 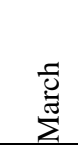 & $\overline{\bar{z}}$ & $\vec{\Xi}$ & $\Xi$ & 引 & 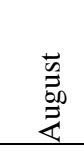 & 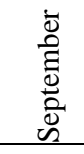 & $\begin{array}{l}\dot{0} \\
\stackrel{0}{0} \\
\dot{0} \\
0\end{array}$ & $\begin{array}{l}\dot{\bar{D}} \\
\bar{E} \\
\overline{0} \\
0 \\
0 \\
Z\end{array}$ & 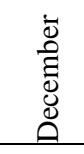 & $\begin{array}{l}\text { Annual } \\
\text { Rainfall } \\
(\mathrm{mm})\end{array}$ \\
\hline 2006 & 16.6 & 9.8 & 33.8 & 80.6 & 60.4 & 33.2 & 57.8 & 12.4 & 23.8 & 76.4 & 54.4 & 10.0 & 469.2 \\
\hline 2007 & 34.8 & 9.4 & 35.0 & 60.2 & 36.4 & 46.2 & 15.6 & 70.0 & 0.0 & 30.2 & 95.8 & 14.8 & 448.8 \\
\hline 2008 & 30.8 & 12.5 & 41.0 & 78.0 & 45.0 & 36.0 & 18.6 & 26.6 & 27.6 & 26.0 & 60.5 & 12.3 & 414.9 \\
\hline Mean & 27.4 & 10.6 & 36.6 & 72.9 & 47.3 & 38.5 & 30.7 & 36.3 & 17.1 & 44.2 & 70.2 & 12.4 & 444.2 \\
\hline
\end{tabular}

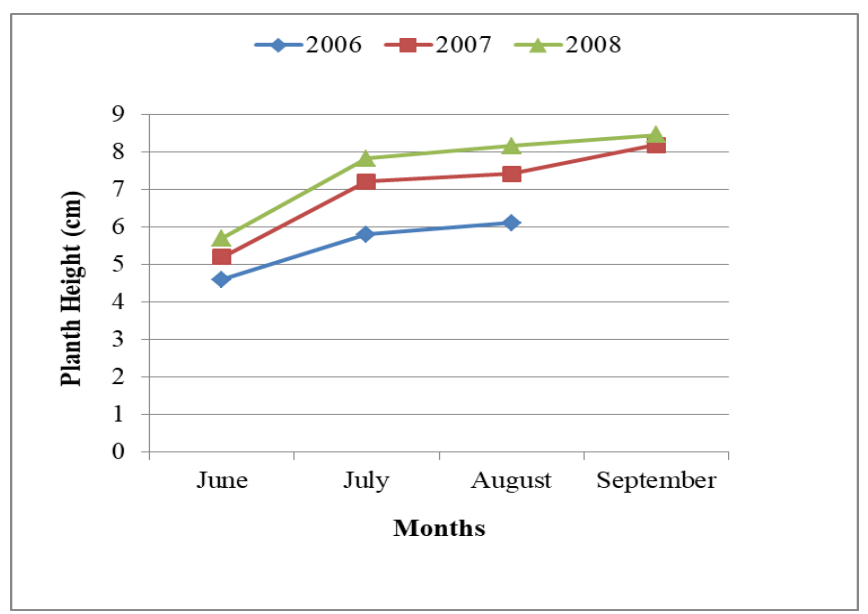

Figure 2. Average plant height development of the caper over the years.

When Figure 2 is examined, it is seen that caper does not show the desired plant development. As a matter of fact, it is stated in the survey made by Özturan 2007 that the plant height of caper reached $65.30 \mathrm{~cm}$ in June in the first year following planting, and $98.33 \mathrm{~cm}$ in August. On the other hand, after June, the caper seedlings was irrigated once in a week in order to improve the adaptation mechanism and plant growth against hot and dry temperature (Özturan, 2007). Study area was established in eroded site. Considering the general soil characteristics of the research area, it can be said that the high clay content in the area and the low amount of sand have an adverse effect on the adaptation and development of caper seedlings in the area. Therefore, it was thought that soil characteristic of the study area had negative effects on plant growth. The soil texture of research plots is clay or clay loam. Therefore, it can be concluded that this high clay content negatively affect the development of caper seedlings in the research area. It was reported that the caper is best developed in the $\mathrm{pH}$ ratio between 6.3 and 8.3 (Kara et al., 1996) in sandy loam soils which has high lime and organic matter content (Özdemir and Öztürk, 1996). The insufficient of the protective vegetation in the area and the continuous destruction of the bare soil surface, especially by short-term heavy rainfall, negatively affected the soil aggregate structure, especially the top soil. The aggregate structure was deteriorated due to the inadequacy of the vegetation and especially by the short time heavy rain. The deterioration of the soil aggregate structure and the high level of clay in the soil texture may have affected negatively the aeration of the soil, the drainage conditions and the hydrophobic properties of the soil. These changes in the soil characteristics have probably affected the development of caper saplings in the negative direction. For as much as it is stated that soil airflow and the amount of oxygen in the soil air are very important for the saplings during the growing (Brady and Weil, 1999; Yüksek et al., 2009). Although the total annual amount of rainfall in the research area is sufficient for capari development, the large irregularities in the monthly distribution of rainfall, the slow growth of caper root development in the early days of growth, clay fractions in the soil and inadequate soil water may had been a negative effect on the growth of caper seedlings. The highest sediment yield was measured in caper plots; while the lowest runoff was measured in bare plots (Table 3).

Table 3. Average runoff, sediment yield and sediment concentration in experimental plots (Values represent the mean \pm standard deviation).

\begin{tabular}{lccc}
\hline Treatment & $\begin{array}{c}\text { Runoff } \\
(\mathrm{mm})\end{array}$ & $\begin{array}{c}\text { Sediment Yield } \\
\left(\mathrm{g} \mathrm{m}^{-1}\right)\end{array}$ & $\begin{array}{c}\text { Sediment Concentration } \\
\left(\mathrm{g} \mathrm{l}^{-1}\right)\end{array}$ \\
\hline Bare & $0.49 \pm 0.73 \mathrm{a}$ & $8.76 \pm 17.70 \mathrm{a}$ & $8.09 \pm 8.34 \mathrm{a}$ \\
Caper & $0.48 \pm 0.71 \mathrm{a}$ & $9.84 \pm 19.91 \mathrm{a}$ & $9.78 \pm 11.98 \mathrm{a}$ \\
Sig. Level & 0.922 & 0.694 & 0.259
\end{tabular}

If the same letter appears within-column, differences are not significant at the $5 \%$ level.

There was no statistical difference in surface flow, sediment yield and sediment concentration between the bare plots and and caper plots. The clusters in the research parcels have not developed a development that could protect against the erosion of the land. Acar et al., (2002) studied on the erosion areas in Manisa-Sarıgöl region; it was found that caper did not directly affect the top soil loss during the study period because it gave life struggle in the first two years and tried to strengthen the root system. However, from the third year onwards, it has been determined that the plants grow horizontally by giving long shoots and can make up to three meters of peak diameter, and that the plant residue accumulated on the soil surface of the caper can make an erosion preventive effect from the third year onwards. 
The changes in surface runoff, sediment yield and sediment concentration according to years and seasons are given in Table 4 and Table 5.

Table 4. Average runoff, sediment yield and sediment concentration in experimental plots according to years. (Values represent the mean \pm standard deviation).

\begin{tabular}{lccc}
\hline Year & $\begin{array}{c}\text { Runoff } \\
(\mathrm{mm})\end{array}$ & $\begin{array}{c}\text { Sediment Yield } \\
\left(\mathrm{g} \mathrm{m}^{-1}\right)\end{array}$ & $\begin{array}{c}\text { Sediment Concentration } \\
\left(\mathrm{g} \mathrm{l}^{-1}\right)\end{array}$ \\
\hline 2006 & $0.68 \pm 0.88 \mathrm{a}$ & $16.81 \pm 25.02 \mathrm{a}$ & $13.52 \pm 15.22 \mathrm{a}$ \\
2007 & $0.31 \pm 0.33 \mathrm{ab}$ & $2.29 \pm 2.66 \mathrm{~b}$ & $6.26 \pm 2.24 \mathrm{a}$ \\
2008 & $0.10 \pm 0,09 \mathrm{~b}$ & $0.36 \pm 0.25 \mathrm{c}$ & $3.78 \pm 1.43 \mathrm{~b}$ \\
Sig. Level & 0.000 & 0.000 & 0.000
\end{tabular}

If the same letter appears within-column, differences are not significant at the $5 \%$ level.

Table 5. Table Average runoff, sediment yield and sediment concentration from experimental plots according to seasons (Values represent the mean \pm standard deviation).

\begin{tabular}{lccc}
\hline Season & $\begin{array}{c}\text { Runoff } \\
(\mathrm{mm})\end{array}$ & $\begin{array}{c}\text { Sediment Yield } \\
\left(\mathrm{g} \mathrm{m}^{-1}\right)\end{array}$ & $\begin{array}{c}\text { Sediment Concentration } \\
\left(\mathrm{g} \mathrm{l}^{-1}\right)\end{array}$ \\
\hline Spring & $0.03 \pm 0.03 \mathrm{c}$ & $0.09 \pm 0.12 \mathrm{c}$ & $3.09 \pm 2.18 \mathrm{~b}$ \\
Summer & $0.94 \pm 0.84 \mathrm{a}$ & $21.04 \pm 25.25 \mathrm{a}$ & $17.11 \pm 14.51 \mathrm{a}$ \\
Autumn & $0.22 \pm 0.19 \mathrm{~b}$ & $0.95 \pm 0.95 \mathrm{~b}$ & $4.64 \pm 1.14 \mathrm{~b}$ \\
Sig. Level & 0.000 & 0.000 & 0.000 \\
\hline
\end{tabular}

If the same letter appears within-column, differences are not significant at the $5 \%$ level.

As seen in both Tables 4 and 5, the runoff, sediment yield and sediment concentration change with years and seasons is a statistically significant level. It is also stated that the superficial flow of the monthly and seasonal distribution of rain influences the sediment yield and the sediment coefficient (Yüksek and Yüksek, 2015). Chirino et al. (2006), reported that rainfall characteristics (such as frequency, duration, quantity and intensities) are also influential in rainfall flow relations as well as vegetation characteristics (closure, root and body structure). Andreu et. al (1998) reported that evolution of the rain regime which affected the development of vegetation also greatly influenced erosion parameters.

\section{CONCLUSIONS and RECOMMENDATIONS}

It has been determined that the adaptation and development of the caper seedlings in the clayey soil in eroded site not in the desired level. Percentage of survival rate of caper seedlings was found to be quite low (24\%) in the first years following planting. Therefore, during the first season of planting, the texture of soil and summer drought during the growing season had adversely affected the development and survival percentage of caper saplings. Throughout the research period, the development of the caper saplings was not at the desired level. As a result, the plant did not protect the soil from erosive rain. In addition, it has been determined that the effect of rain erosivity changes with the season and years. Both soil properties and rain characteristic (such as: the amount of rainfall, type of rainfall and the distribution of rainfall) are quite effective on plant growth in eroded sites. Therefore, the combination of erosion control techniques such as mulching, terracing and irrigation might be increased the survival percentage of caper saplings and soil conservation ability in eroded sites. It is very well known that mulching the soil surface with a layer of plant residue conserves water and soil because mulch reduces surface runoff, increases water infiltration into the soil and retards soil erosion (Ghawi and Battikhi, 1986; Adekalu et al., 2007; Smets et al., 2008). But it should not be forgotten that the plant material for mulching was only available and efficient after the wet years. For this reason, the plants to be used in mulching should be carefully selected.

\section{Acknowledgements}

This research was funded by the Scientific and Technological Research Council of Turkey (TUBITAK) with the Project number TOVAG-104O116 (2005-2009).

\section{REFERENCES}

Acar, C., Bilgin, F. \& Gül, A. (2002). Manisa Sarlgöl Yöresindeki Erozyon Sahalarında OrmancılıKarma Ormancılık-Tarım-Mera Amaçlı Kullanım Tekniklerine Uygun Bazl Bitki Türlerinin Belirlenmesi ve Erozyon Kontrolü Üzerine Etkileri. Teknik Bülten No: 019, Orman Bakanlığı Yayın No: 155, Ankara.

Adekalu, K.O., Olorunfemi, I.A. \& Osunbitan, J.A. (2007). Grass mulching effect on infiltration, surface runoff and soil loss of three agricultural soils in Nigeria. Bioresource Tech, 98, 912-917.

Andreu, V., Rubio, J.L., Gimeno-García, E. \& Llinares, J.V. (1998). Testing three Mediterranean shrub species in runoff reduction and sediment transport. Soil and Tillage Research, 45(3-4), 441-454.

Angima, S.D., Stott, D.E., O'Neill, M.K., Ong, C.K. \& Weesies, G.A. (2002). Use of callindra-Napier grass contour hedges to control erosion in central Kenya. Agric. Ecosyst. Environ., 91, 15-23.

Babalola, O., Oshunsanya, S.O. \& Are, K. (2007). Effects of vetiver grass (Vetiveria nigritana) strips, vetiver grass mulch and an organomineral fertilizer on soil, water and nutrient losses and maize (Zea mays, L) yields. Soil Tillage Res., 96, 6-18.

Brady, N.C. \& Weil, R.R. (1999). The Nature and Properties of Soils. New Jersey: Prentice Hall Publishing.

Calvo-Cases, A., Boix-Fayos, C. \& Imeson, A.C. (2003). Runoff generation, sediment move-ment and soil water behaviour on calcareous (limestone) slopes of 
some Mediterra-nean environments in southeast Spain. Geomorphology, 50, 269-291.

Dokuz, A. (2000). Geology, geotectonics, geochemistry and petrogenesis of magmatic and metamorphic rocks in Yusufeli (Artvin-Turkey)]. Ph.D. thesis, Karadeniz Technical University, Trabzon-Turkey [in Turkish, unpublished], $311 \mathrm{p}$.

Garcia-Estringana, P., Alonso-Blázquez, N., Marques, M.J., Bienes, R., González-Andrés, F. \& Alegre J. (2013). Use of Mediterranean legume shrubs to control soil erosion and runoff in central Spain. A large-plot assessment under natural rainfall conducted during the stages of shrub establishment and subsequent colonisation. Catena, 102, 3-12.

Chirino, A., Bonet, J. \& Sanchez, J.R. (2006). Effects of 30-year-old Aleppo pine plantations on runoff, soil erosion, and plant diversity in a semi-arid landscape in south eastern Spain. Catena, 65(1), 19-29.

Ghawi, I. \& Battikhi, A. (1986). Water melon production under mulch and trickle irrigation in the Jordan Valley. Journal of Agronomy and Crop Sci., 157, 145-155.

Kara, Z., Ecevit, F. \& Karakaplan, S. (1996). Toprak koruma elemanı ve yeni bir tarımsal ürün olarak kapari (Capparis sp.). Tarım-Çevre İlişkileri Sempozyumu, Mersin, pp. 919-929.

Kelkit, A. \& Müftüoğlu, M. (2001). Çanakkale yöresi tarımında ve erozyonla mücadelede kapari (Capparis spinosa L.)'nin önemi. Atatürk Üniver., Ziraat Fakültesi Dergisi, 32 (3), 329-333.

Kothyari, B.P., Verma, P.K., Joshi, B.K. \& Kothyari, U.C., (2004). Rainfall-runoff-soil and nutri-ent loss relationships for plot size areas of Bheta $\mathrm{Gad}$ watershed in Central Himalaya. India. J. Hydrol., 293, 137-150.

Li, X.Y., Gao, S.Y., Xu, H.Y. \& Liu, L.Y. (2006). Growth of Caragana korshinskii using runoff-collecting microcatchments under semiarid condition. Journal of Hydrology, 328(1-2), 338-346.

Martínez Raya, A., Durán Zuazo, V.H. \& Francia Martínez, J.R. (2006). Soil erosion and runoff response to plant-cover strips on semiarid slopes (SE Spain). Land Degradation and Development, 17(1), 1-11.

Mohammad, A.G. \& Adam, M.A. (2010). The impact of vegetative cover type on runoff and soil erosion under different land uses. Catena, 81(2), 97-103.

Nunes, A.N., de Almeida, A.C. \& Coelho, C.O.A. (2011). Impacts of land use and cover type on runoff and soil erosion in marginal area of Portugal. Appl. Geogr., 31, 687-699.

Ölmez, Z. (2001). Capparis ovata Desf. (kapari)'nın Fidanlık Tekniği ve Artvin Yöresinde Plantasyon Denemeleri. Doktora Tezi, KTÜ Fen Bilimleri Enstitüsü, Trabzon, 144 s.
Özdemir, F. \& Öztürk, M. (1996). Batı Anadolu'da yayılış gösteren Capparis L. türlerinin bireysel ekolojisi üzerine bir araştırma, Turkish Journal of Botany, 20(2), 189-199.

Özturan, S. (2007). Çukurova Koşullarında Capparis ovata'da Farklı Ekim Siklklarının Verime Etkisi, Yüksek Lisans Tezi, Çukurova Üniversitesi Fen Bilimleri Enstitüsü, Adana, $47 \mathrm{~s}$.

Smets, T., Poesen, J. \& Knapen, A. (2008). Spatial scale effects on the effectiveness of organic mulches in reducing soil erosion by water. Earth-Science Reviews, 89,1-12.

Yüksek, F. \& Yüksek, T. (2007). Artvin Yusufeli yöresinde korunganın toprak koruma yeteneğinin belirlenmesi. Türkiye VII. Tarla Bitkileri Kongresi, 25-27 Haziran 2007, Erzurum, Bildiriler 2 Çayır Mera Yem Bitkileri ve Endüstri Bitkileri, 143-147.

Yüksek, T., Yüksek, F., Özalp, M. \& Ölmez, Z. (2009). Artvin pamukçular yöresinde kapari (Capparis ovata Desf.) ve korunganin (Onobrychis viciifolia Scop.) toprak koruma yeteneklerinin karşılaştırılması. TÜBİTAK-TOVAK Proje No:1040116, 65 pp.

Yüksek, T. \& Yüksek, F., (2011). The effects of restoration on soil properties in degraded land in the semi-arid region of Turkey. Catena, 84(1-2), 47-53.

Yüksek, F. \& Yüksek, T., (2015). Growth performance of sainfoin and its effects on the runoff, soil loss and sediment concentration in a semi-arid region of Turkey. Catena, 133, 309-317.

Zhang, G.H., Liu, G.B. \& Wang, G.L. (2010). Effects of Caragana Korshinskii Kom. cover on runoff, sediment yield and nitrogen loss. International Journal of Sediment Research., 25(3), 245-257.

Zhou, Z.C. \& Shangguan, Z.P. (2008). Effect of Ryegrasses on Soil Runoff and Sediment Control. Pedosphere, 18(1), 131-136.

Xu, X.L., Ma, K.M., Fu, B.J., Liu, W. \& Song, CJ. (2009). Soil and water erosion under different plant species in a semiarid river valley, SW China: the effects of plant morphology. Ecological Research, 24(1), 37-46.

Received date: 25.02 .2018

Accepted date: 20.04 .2018

*Corresponding author's:

Prof. Dr. Turan YÜKSEK

Recep Tayyip Erdoğan Üniversitesi, Güzel Sanatlar, Tasarım ve Mimarlık Fakültesi, Peyzaj Mimarlığı Bölümü, Zihni Derin Yerleşkesi, Fener Mah., 53100, Rize, Türkiye.

E-mail: turan.yuksek@erdogan.edu.tr 